\title{
Public Health LaW: Power, Duty, Restraint by lawrence O. Gostin (Berkeley: University of California Press, 2000)
}

The study of Canadian health law has traditionally conformed to a well-established paradigm, centred around the physician-patient relationship (more recently broadened to include other health care providers as health care delivery has been reorganized across Canada). Within this paradigm a wide array of legal issues have been identified and analyzed during the past half century: in the 1950 s and $1960 \mathrm{~s}$, the principles of clinical negligence largely took shape; ${ }^{\prime}$ the 1980 s and 1990 s witnessed a significant recasting of the principles of informed consent; ${ }^{2}$ and in the $1990 \mathrm{~s}$, first the common law, and then Parliament and provincial legislatures turned their attention to confidentiality and other health information issues. ${ }^{3}$ Leading Canadian health law textbooks ${ }^{4}$ and health law teaching have relied heavily on these central organizing principles.

By contrast, public health law has traditionally been the poor cousin, largely ignored as a subject of legal study and, when considered at all, has been fragmented across a broad spectrum of legal subjects, including constitutional law, Charter law, environmental law, disability law and many others.

Recently, public health and safety issues have gained considerable profile, yet they have been given short shrift in legal literature. Consider just a few recent examples: the water contamination incidents in Walkerton and Battleford; the anthrax scare following 11 September; the first diagnosis of a new variant of Creuzfeldt-Jacob disease in Canada; bicycle helmet safety legislation; the debate over labelling of genetically modified foods; the tension between new federal privacy legislation and cancer surveillance programs; and the legal struggle around tobacco advertising. The need for a coherent and comprehensive examination of public health law and its role in protecting the health of the public has become increasingly pressing. Likewise, there is an emerging need to distinguish "public" from "private" health law in a more systematic way.

Fortunately, Lawrence Gostin's Public Health Law: Duty, Power, Restraint has recently been published. It invites us to consider a new, public health law-centred paradigm of legal thinking and education. As a bonus it provides a readable, comprehensive view of how public health law can be identified, analyzed and adapted to the many issues that demand its attention.

See Crits v. Sylvester, [1956] S.C.R. 991; Wilson v. Swanson (1956). 5 D.L.R. (2d) 113 (S.C.C.). Reibl v. Hughes, [1980] 2 S.C.R. 880; Hopp v. Lepp, [1980] 2 S.C.R. 192; and, much later, Arndt v. Simith (1997), 148 D.L.R. (4th) 48 (S.C.C.).

McInerney v. Macdonald, [1992] 2 S.C.R. 138; Personal Information Protection and Electronic Documents Act, S.C. 2000, c. 5; Health Information Act. R.S.A. 2000, c. 4.8.

The leading Canadian texts, in this writer's view, are (in no order of preference) E. Picard \& G. Robertson, Legal Liability of Doctors and Hospitals in Canada, 3d ed. (Scarborough: Carswell, 1996); and J. Downie, T. Caulfield \& C. Flood, eds., Canadian Health Law and Policy. 2d ed. (Toronto: Butterworths, 2002). 
Gostin's book is specifically focused on the American experience of public health, and consequently devotes a great deal of its analysis to the constitutionalization of public health in the United States. This is not a traditional Canadian approach to public health law, but it is conceivable that it could become so in the not-too-distant future. Moreover, in describing the evolution of public health regulation in the United States, Gostin describes many elements that mirror the Canadian landscape. Not least important amongst these common elements is the confusion around public health regulation between and within jurisdictions, because much of American public health law, as in Canada, is an untidy mess of statutory and other legal instruments accreted by state and municipal governments. "Antiquity," as well as "fragmentation," employed by Gostin to label the current state of American public health law, are adjectives equally descriptive of the Canadian context.

Gostin threads throughout his book the important theme that, because the central objective of public health policy and activity is to create "the conditions for people to lead healthier lives," conflict with rights and interests of individual persons is inevitable. This pervasive tension embeds politics in public health decision-making, and makes public health law an essential element of any ongoing solutions.

However, the appeal of Gostin's book lies less in the articulation of his central thesis than in the way that he seeks to prove it - by cross-cutting diverse areas of law in order to develop a public health law paradigm that is quite distinct from the traditional version. He does this in two ways: first, by identifying five essential distinctive characteristics of public health law; and second, by examining six distinctive types of public health activities that engage the legal protection of individual rights. These discussions do not occupy the whole of the book, but they are the most usefully translatable into the Canadian context.

The five defining characteristics of public health, as articulated by Gostin, are government (that public health activities are a special responsibility of government); populations (that public health focuses on the health of populations); relationships (that public health addresses government-public relationships); services (that public health activities are population-, not individual-based); and coercion (that public activities are largely coercive, not voluntary). ${ }^{6}$ Public health law, argues Gostin, is central to public health activity: "The law ... is used to influence norms for healthy behaviour, identify and respond to health threats, and set and enforce health and safety standards. The most important social debates about public health take place in legal fora - legislatures, courts and administrative agencies - and in the law's language of rights, duties and justice." The "noise" around public health has traditionally been muted in Canada, but the Walkerton inquiry and the Krever Inquiry into the Canadian blood system have clearly illustrated how a public health emergency can very rapidly turn up the volume.

L.O. Gostin, Public Health Law: Power, Duty, Restraint (Berkeley: University of California Press, 2000) at 309 [emphasis added].

As illustrated by the first of many excellent graphical descriptions, ibid. at 5 .

Ibid. 
The central difficulty with defining the scope of public health law typically has been how its various facets are connected. Gostin employs a model that analyzes six types of public health activities and their engagement with law. The first type of activity has to do with health information collection, use, and disclosure, and its conflict with legal principles of personal privacy. These activities encompass public health surveillance, reporting, partner notification, and population-based research. Though largely operating below the radar of public consciousness, and modestly regulated in Canada, these activities have produced significant public health benefits, including the early detection of health threats, the promotion of behavioural, social and environmental changes and the communication of useful, accurate information to citizens and policy-makers. Ironically, however, the arrival of comprehensive information privacy laws, designed to achieve "medical" or "decisional" privacy objectives, have likely inadvertently raised a potentially major obstacle to public health surveillance and population research.

The second type of activity has to do with public communication directed at modifying individual behaviour and its conflict with freedom of expression. These activities encompass health education campaigns, restraints on commercial speech, and "compelled commercial speech." The two-sided mirror of generating messages to promote healthy behaviour, and suppressing commercial messages that promote unhealthy behaviour, raise important legal and ethical issues of truth-telling and "public-spirited" deception by governments, and the limits of free commercial expression. Tobacco advertising exemplifies this tension.

The third type of activity has to do with immunization, testing, and screening, and their conflict with personal bodily integrity. The struggles for religious exemptions to vaccinations, and against discrimination against secular objectors, as well as the nuanced voluntary-to-involuntary spectrum of activities like maternal HIV screening to reduce perinatal transmission and the legal difficulties associated with mandated compliance represent two scenarios that engage as yet unresolved legal debate.

The fourth type of activity imposes restrictions on choices and liberties available to individuals presenting a public health risk. These activities, which exemplify the traditional core of public health, encompass quarantine, isolation, civil commitment, compulsory examination and treatment, and criminal penalties for knowingly or wilfully exposing others to health risk. Complex conflicts with autonomy, liberty and bodily integrity is implicit in these activities, as is illustrated by the examples of mandatory treatment of HIV-postive women and individuals who engage in frequent unprotected sexual activity.

The fifth and sixth types of public health activities regulate business proprietors and property owners, and thereby raise conflicts with professional, property and business interests. The method of regulation may be direct, such as licensing or inspection, or indirect through the behaviour-modifying effect of tort law. Direct regulation engages administrative law principles in all provinces. Gostin's analysis of eleven precedentsetting product lawsuits involving firearms during the past 30 years $^{8}$ and three waves 
of American tobacco litigation provide a plausible preview of the future impact of tort law on Canadian public health activities and regulation.

In the final chapter of his book, Gostin departs from his descriptive method and outlines his vision of public health law reform. His prescription - a consistent and uniform legislative approach, with clear objectives and adequate guarantees of due process and protection against discrimination and invasion of privacy - is not particularly original as a matter of modern legislative theory, but is long overdue for public health and an important primer for any legislators in this area. The explicit balancing of public against private interests is not new, but the emergence of privacy law and individual human rights law in the public health discourse introduces new and interesting analytical tools. Harmonization of public health policy and law, a concept implicit in Professor Gostin's treatment of this subject, is arguably significantly further advanced in the United States. Canadian policy-makers and legislators could derive valuable lessons from the American experience.

This is a rare textbook that can be read and readily absorbed by lawyers, health care professionals and policy- and law-makers alike. It may, and should, catalyze the development of a distinctive Canadian subject area of public health law. At the very least it has inserted public interest and human rights perspectives into mainstream health law discourse in a way that is likely to have significant effects in the years to come.

\author{
Brent Windwick \\ Executive Director \\ Health Law Institute \\ University of Alberta
}

